\title{
GEJALA MAKNA PREFIKS BAHASA KEPULAUAN TUKANG BESI DIALEK KALEDUPA
}

\author{
Asrul Nazar \\ Prodi Pendidikan Bahasa dan Sastra Indonesia, Fakultas Keguruan dan Ilmu Pendidikan \\ Universitas Muhammadiyah Buton, Jl. Betoambari No. 36 Baubau. \\ E-mail: asrulnazar@gmail.com
}

\begin{abstract}
Abstrak
Tujuan penelitian untuk mengetahui Gejala Makna Prefiks Bahasa Kepulauan Tukang Besi Dialek Kaledupa Kaledupa. Hasil penelitian menunjukan bahwa bahasa Kepulauan Tukang Besi dialek Kaledupa terdapat beberapa macam prefiks yang dapat mengubah makna ketika ditambahkan kata dasar yaitu; nodan po-. Prefiks no- yang dibentuk dari bentuk kata dasar yang berupa verba, maka hasil perubahan maknanya melalui prefiks no- tetap menjadi verba yang mengacu pada suatu tindakan. Prefiks po- jika digabungkan dengan bentuk kata dasar yang berupa, verba, nomina dan adjektiva maka hasil perubahan maknanya melalui prefiks po- akan menjadi verba tetap menjadi verba tetapi mengalami perubahan makna yang mengacu pada suatu aktivitas atau kegiatan.
\end{abstract}

Kata kunci: gejala makna, prefiks, bahasa daerah.

\begin{abstract}
The purpose of the study is to find out the Symptoms of the Meanings of the Prefix of the Kaledupa Kaledupa Ironworker Islands Language. The results of the study show that the Ironman Islands language of the Kaledupa dialect contains several kinds of prefixes that can change meaning when adding basic words, namely; no- and po-. The no- prefix formed from the basic word form in the form of a verb, then the result of changing its meaning through a no-prefix remains a verb that refers to an action. If the prefix is combined with the basic form of words, verbs, nouns and adjectives, the result of the change in meaning through the po-prefix will be a verb which remains a verb but changes in meaning that refers to an activity or activity.
\end{abstract}

Keywords: symptom of meaning, prefix, regional language. 


\section{SANG PENCERAH}

Volume 4, Nomor 1, Februari 2018, Hlm. 1-4

Asrul Nazar: Prefiks Bahasa Kepulauan Tukang Besi ...

\section{Pendahuluan}

Bangsa Indonesia terdiri atas berbagai suku yang mempunyai keanekaragaman budaya serta latar belakang yang berbedabeda. Secara umum bahasa adalah alat untuk berinteraksi atau berkomunikasi berupa lambang bunyi yang dihasilkan alat ucap manusia, untuk menyampaikan pikiran, gagasan, konsep atau perasaan seseorang. Bahasa Indonesia mempunyai kedudukan yang sangat penting dalam kehidupan Bangsa dan Negara Indonesia. Hal ini dapat dilihat dari kedudukan dan fungsi Bahasa Indonesia dalam bahasa Negara.

Bahasa Indonesia dalam kedudukannya sebagai bahasa nasional berfungsi: (1) lambang kebanggaan nasional; (2) lambang identitas nasional; (3) alat pemersatu berbagai masyarakat yang berbeda-beda latar belakang sosial budaya dan bahasanya; dan (4) alat perhubungan antar budaya dan daerah. Bahasa Indonesia dalam kedudukannya sebagai bahasa Negara berfungsi: (1) bahasa resmi kenegaraan; (2) bahasa pengantar resmi di lembaga-lembaga pendidikan; (3) bahasa resmi di dalam perhubungan tingkat nasional untuk kepentingan perencanaan dan pelaksanaan pengembangan serta pemerintah; dan (4) bahasa resmi dalam pengembangan kebudayaan dan pemanfaatan ilmu pengetahuan serta teknologi modern.

Masyarakat yang sedang berkembang pada segala bidang kehidupannya seperti politik, ekonomi, sosial, dan budaya, biasanya akandiikuti pula oleh perkembangan bahasanya. Perkembangan ilmu pengetahuan dan teknologi juga mengakibatkan perkembangan bahasa. Hal tersebut menunjukkan makin maju suatu bangsa serta makin modern kehidupannya, makin berkembang pula bahasanya. Perkembangan bahasa harus sejalan dan seiring dengan kemajuan kebudayaan serta peradaban bangsa sebagai pemilik dan pemakai bahasa tersebut Badudu dalam (Putrasaya, 2008: 1).

Bahasa daerah selain sebagai alat komunikasi dan interaksi sosial, juga mempunyai peranan sebagai alat untuk melakukan kegiatan kebudayaan sekaligus bagian dari kebudayaan sendiri. Bahasa daerah merupakan bahasa Ibu yang perlu dilestarikan karena bahasa daerah merupakan bagian dari kebudayaan daerah dan juga merupakan unsur dari kebudayaan nasional. Sebagai negara yang multikultural Indonesia memiliki beraneka ragam suku, bahasa, budaya, dan ras. Indonesia memiliki banyak bahasa daerah yang semakin memperkaya budaya bangsa. Salah satunya yaitu bahasa Kepulauan Tukang Besi yang wilayah tuturnya di Kepulauan Wakatobi.

Bahasa Kepulauan Tukang Besi, memiliki empat dialek besar, yaitu Dialek Wangi-wangi, Kaledupa, Tomia, dan Binongko. Untuk memperkaya pendokumentasian bahasa daerah, penelitian ini perlu dilakukan dengan fokus penelitian bagaimanakah Gejala Makna Prefiks Bahasa Kepulauan Tukang Besi Dialek Kaledupa Kaledupa?

Tujuan penelitian untuk mengetahui Gejala Makna Prefiks Bahasa Kepulauan Tukang Besi Dialek Kaledupa Kaledupa.

\section{Metode Penelitian}

Metode yang digunakan dalam penelitian ini adalah deskriptif-kualitatif. Deskriptif, yakni suatu metode yang menggambarkan data secara alamiah, serta menghasilkan kaidah-kaidah kebahasaan secara linguistik (Djajasudarma dalam Muhammad,2011: 193). Jenis penelitian ini termaksud penelitian lapangan.

Data yang digunakan dalam penelitian ini berupa data lisan dan tulisan. Data lisan yang dimaksud adalah data yang berasal dari percakapan lisan bahasa daerah Kepulauan Tukang Besi Dialek Kaledupa Kaledupa yang digunakan dalam 


\section{SANG PENCERAH}

Volume 4, Nomor 1, Februari 2018, Hlm. 1-4

Asrul Nazar: Prefiks Bahasa Kepulauan Tukang Besi ...

percakapan sehari-hari oleh masyarakat setempat. Sedangkan data tulis sebagai data pendamping untuk memperoleh data yang kompleks.

\section{Pembahasan}

\section{Presfiks Bahasa Kepulauan Tukang Besi Dialek Kaledupa}

Proses perubahan makna prefiks dalam bahasa Kepulauan Tukang Besi Dialek Kaledupa tersebut terjadi melalui prefiks no-, pa-, dan po-. Proses perubahan makna prefiks tersebut berimplikasi pula denganperubahan kelas kata tersebut atau terjadi proses derivasional.

\section{Makna Prefiks no-}

Makna prefiks dalam bahasa Kepulauan Tukang Besi dialek Kaledupa dapat terjadi melalui prefiks no-. Perhatikan beberapa data berikut.

Fadi nopajere tekadola nuompusu

'Fadi mengejar ayam nenekku'

\section{Fatir nofila ae kua sikola'a}

'Fatir berjalan kaki ke sekolah'

Makna prefiks no- dalam bahasa Kepulauan Tukang Besi dialek Kaledupa, berdasarkan data yang dianalisis terdapat perubahan dan juga tidak terdapat perubahan makna ketika terjadi pembubuhan afiksasi no-. Perubahaan makna afiksasi no- diikuti pula dengan perubahan kelas kata atau terjadi derivasional pada kata tertentu. Pada kata pajere 'kejar' (v) ketika terjadi pembubuhan prefiks no- menjadi nopajere 'mengejar' (v) tidak mengalami perubahan kelas kata tersebut. Pada data kedua nofila, dapat dinyatakan bahwa terdapat perubahan makna dan kelas kata (derivasional). Kata fila 'jalan' (n) setelah dibubuhkan prefiks no- menjadi nofila 'berjalan' (v). Makna prefiks no- dalam bahasa Kepulauan
Tukang Besi dialek Kaledupa mengacu pada suatu 'tindakan'.

\section{Makna Prefiks $p a-$}

Selain makna prefiks no-, afiksasi dalam bahasa Kepulauan Tukang Besi dialek Kaledupa, adapula makna prefiks pa-. Perhatikan data-data berikut ini.

\section{Andi kuitae pafila temottoro}

'Saya lihat Andi mengendarai motor'

Ompusu pasangki nubaju kabaea

'Nenekku penjahit baju kebaya'

Berdasarkan analisis data, dinyatakan bahwa tidak adanya perubahan makna fila 'jalan' (n) melalui penambahan prefiks $p a-$ menjadi pafila 'mengendarai' (n). Pada data berikutnya dinyatakan bahwa adanya perubahan makna sangki 'jahit'(v) melalui penambahan prefiks $p a-$ menjadi pasangki 'penjahit'(n). Perubahan makna prefiks padalam bahasa Kepulauan Tukang Besi dialek Kaledupa pada kata pasangki mengacu pada mengacu pada 'aktivitas'.

\section{Makna Prefiks po-}

Selain prefiks no-, $p a-$ adapula prefiks po- yang terdapat dalam bahasa Kepulauan Tukang Besi dialek Kaledupa. Perhatikan data berikut.

La Andi kene La rudi pobusu raga ako tebagulli 'Andi dan rudi berkelahi hanya untuk kelereng'

Inasu poafa kene suluno dhidaoa

'Mamaku bertemu dengan saudaranya di pasar'

Wa Citra poroppu kene kene-keneno mai di kotamara

Citra berkumpul dengan teman-temannya di kotamara.

Berdasarkan hasil analisis data tersebut, bahwa terlihat adanya perubahan 


\section{SANG PENCERAH}

Volume 4, Nomor 1, Februari 2018, Hlm. 1-4

Asrul Nazar: Prefiks Bahasa Kepulauan Tukang Besi ...

makna pada kata busu 'tinju' (n) setelah penambahan prefiks po- menjadi pobusu 'berkelahi' (v). Data berikunya pun juga terlihat adanya perubahan makna pada kata afa 'dapat'(Adv) ketika dibubuhkan prefiks po- menjadi poafa'bertemu'(v). Data selanjutnya dapat dinyatakan bahwa terlihat tidak adanya perubahan makna pada kata roppu 'kumpul' (v) ketika ditambahkan prefiks po- menjadi poroppu 'berkumpul' (v). Perubahan makna prefiks po- mengacu pada suatu 'kegiatan atau aktivitas'.

\section{Simpulan}

Simpulan penelitian ini bahwa dalam bahasa Kepulauan Tukang Besi dialek Kaledupa terdapat beberapa macam prefiks yang dapat mengubah makna ketika ditambahkan kata dasar yaitu; no- dan po-. Prefiks no- yang dibentuk dari bentuk kata dasar yang berupa verba, maka hasil perubahan maknanya melalui prefiks notetap menjadi verba yang mengacu pada suatu tindakan. Prefiks po- jika digabungkan dengan bentuk kata dasar yang berupa, verba, nomina dan adjektiva maka hasil perubahan maknanya melalui prefiks poakan menjadi verba tetap menjadi verba tetapi mengalami perubahan makna yang mengacu pada suatu aktivitas atau kegiatan.

\section{Daftar Pustaka}

Alwi, Hasan, Dkk. 2003. Tata Bahasa Baku Bahasa Indonesia (Edisi Ketiga). Jakarta: Balai Pustaka.

Alwi. 2003. Fungsi dan Makna Prefiks. Jakarta: Balai Pustaka.

Chaer. 1994. Fungsi dan Makna Prefiks. Jakarta: Erlangga.
2008. Definisi Prefiks. Jakarta:
Rineka Cipta.

Depdikbud. 2009. Definisi Makna. Semarang: Widya Karya.

----------. 2009. Definisi Prefiks. Semarang: Widya Karya.

2009. Definisi Afiks. Jakarta: Balai Pustaka.

Djadjasudarma, T. Fatimah. 1993. Metode Linguistik: Ancangan Metode Penelitian dan Kajian. Bandung: PT Eresco.

Kridaklasana, Harimurti. 2005. Kelas Kata dalam Bahasa Indonesia (Cetakan kedua). Jakarta: PT Gramedia Pustaka Utama. 1999. Fungsi dan Makna Prefiks. Jakarta: Erlangga.

-_. 2008. Difinisi Prefiks. Jakarta: Rineka Cipta.

Marafad, La Ode Sidu dan Nirmala Sari. 2013. Mutiara Bahasa. Yogyakarta: Pustaka Pultika.

Muhammad. 2011. Metode Penelitian Bahasa. Jogjakarta: Ar-Ruzz Media.

Putrasaya, Ida Bagus. 2008. Kajian Morfologi (bentuk derivasional dan infleksional). Jakarta: Refika Aditama.

Ramlan. 2003. Fungsi dan Makna Prefiks. Jakarta: Erlangga.

Yamaguchi, Masao. 2012. Aspek-aspek Bahasa Daerah Sulawesi Selatan. Kyoto: Hokuto Publishing. 